Malikussaleh Journal of Mathematics Learning (MJML)

p-ISSN: 2620-6315 | e-ISSN: 2620-6323

Homepage: https://ojs.unimal.ac.id/mjml/index

\title{
The perspective of university academics on remote teaching during Covid-19 pandemic
}

Zhwan Dalshad Abdullah

Department of Physiotherapy, Erbil Technical Health College, Erbil Polytechnic University, Erbil, Kurdistan Region, Iraq

*Corresponding author: zhwan.dlshad@epu.edu.iq | Phone Number: +9647501184542

\section{ARTICLE INFO}

Received: 11-01-2021

Received in revised: 14-03-2021

Accepted: 18-10-2021

Available online: $30-10-2021$

\section{KEYWORDS}

Perspective;

Academic Staff:

Remote Teaching;

COVID-19 Pandemic;

\begin{abstract}
A B S T R A C T
Coronavirus disease 2019 (COVID-19) has impacted global education, and to prevent the spread of disease, the world have adopted remote teaching. The aim of this study was to determine the university academics perspective towards various aspects of remote teaching during COVID-19 pandemic. According to the findings, the majority of academics had no remote teaching prior experiences and most of them appeared to be unsatisfied with the provided online training of online teaching, online teaching platforms, Internet access, students' participation, online assessment, delivering the content of the subjects they taught, and teaching practical-based subjects. The current study provided essential insights for policymakers in higher education to look over the aspects that hinder the process of remote teaching in Iraq.
\end{abstract}

\section{INTRODUCTION}

COVID-19 is the acronym for coronavirus disease 2019 (Farfán-Cano, 2020). COVID-19 pandemic has created significant challenges for the global higher education community (Crawford et al., 2020). In the light of rising concern about the current pandemic, a growing number of universities across the world (in Africa, Asia, Europe, the Middle East, North America, and South America) have announced school and university closures (UNESCO, 2020; Arnou et al., 2020; Shahzad et al., 2020; Crawford et al., 2020; Kwabena \& Boateng, 2020; Ullah \& Irshad, 2020), and taking intensive measures to protect all the students and staff members from the highly infectious disease (Sahu, 2020). Likewise, the Iraqi government and the Kurdistan Region government shuttered all educational institutions and business venues as well as borders with countries that were hit hard by the COVID-19 virus in early March (Shilani, 2020).

Due to these sudden crisis circumstances, approximately 120 countries have stopped face-to-face learning (Shahzad, 2020) in order to control the risk of virus transmission among students and academics. As a result, teaching and learning processes have globally shifted to online, depending on various platforms like
Google meet, Google class, Zoom, etc. (Gupta et al., 2020). This global shift follows the example set by universities in China where the outbreak first began (Lee, 2020). However, it is not a new common strategy, as closing schools was implemented in many communities when the influenza first appeared (Stern, et al, 2009).

The assessment methodologies were the first thing affected by these closures (Kaur, 2020). As it was claimed by Sahu (2020), shifting from face-to face teaching to online has a serious impact on assessments and evaluation. Several universities depended on online assessment tools which probably have greater measurement error than usual (Upoalkpajor \& Upoalkpajor, 2020) whereas other schools and universities have put their exams on hold for the time being (Kumar, 2020; UNESCO, 2020; Pace et al., 2020).

This rapid transition to online is likely to be difficult for students and academics that are accustomed to traditional classrooms (Crawford et al., 2020). Especially in Iraq, universities were disregarding the remote teaching prior to the Covid-19 outbreak. The studies observed that teachers are concerned about their ability in conducting remote teaching (Duraku \& Hoxha, 2020), the challenges stemming 
from the lack of experience, early preparation for virtual teaching, support from educational technology teams (Bao, 2020; Kwabena \& Boateng, 2020; Pace et al., 2020) as well as many technical difficulties that slow-down the process (Favale et al., 2020). Due to this, some professors are not convinced of the usefulness of distant learning (Lassoued, Alhendawi, Bashitialshaaer, 2020).

The major difficulty is the Internet access that varies from excellent to none depending on the location (Judd et al., 2020), and this limited access to technology and the Internet influenced instructors' and students' ability to engage in remote learning (Zhong, 2020; Pace et al., 2020). The electricity and telecommunication deficit constitutes the other issue (Fawaz \& Samaha, 2020; Gupta et al., 2020). In fact, online learning will be frustrating for the students who are not adequately equipped with basic technological tools and skills (Lee, 2020). To ensure a successful online learning and teaching, providing the necessary tools and connectivity to students (Barton, 2020) and teachers in isolated areas is essential because they cannot afford the costs (Kwabena \& Boateng, 2020).

Shifting to remote teaching raised numerous issues among university academics regarding the quality of education. For instance, laboratory-based subjects' classes cannot be held online (Kumar, 2020). Besides, educational institutions are following the traditional set up of face-toface lectures in a classroom (Dhawan, 2020) unlike developed countries that have opted for this method of teaching long before (Shahzad et al., 2020). In contrast, in developing countries like Iraq, remote teaching was entirely new way for teachers to engage and interact with students in universities. Similarly, online education in Pakistan had a limited existence before the outbreak of Covid-19 (Sarwar, et al., 2020). Thus, teachers are likely to elicit some form of resistance to this rapid change. Ibrahim, et al. (2013) consider teachers' resistance to new changes as an essential obstacle which is mostly associated with how change is initiated and administered.

Although there were negative views of instructors on many online teaching substitutions (Barton, 2020), in the time of the Covid-19 outbreak the use of remote teaching and learning has been considered the most appropriate alternative to keep educational systems functional (Duraku \& Hoxha, 2020; Gaur et al., 2020). Moving instruction online can enable the flexibility of teaching and learning anywhere and anytime (Hodges \& Fowler, 2020). Online learning serves as a panacea during the time of pandemic (Dhawan, 2020); it is a viable solution to cope with lockdown policies (Favale et al., 2020) and a good opportunity for educators and learners to become more creative and innovative (Yokozeki, 2020). Undeniably, they are the powerful tools that can support teaching in the current circumstances (Arnou et al., 2020) and an alternative for the theory classes (Gupta et al., 2020).
Researchers assume that the usage of online collaboration platforms will continue after the COVID-19 disappears (Favale et al., 2020). Likewise, Shahzad et al. (2020) assume that in 10 to 15 years university teaching models will be changed with the massive growth of the Internet. Thus, implementing technology in learning processes and the motivation of instructors to work can influence the process of switching of the educational system from traditional to remote learning (Duraku \& Hoxha, 2020). Consequently, face-to-face instructional method is valuable, but it is essential to combine it with online instruction in higher education (Barboni, 2019).

There is a research gap in the literature concerning elearning systems among universities after the Covid-19 outbreak and higher education closure of physical activities (Shahzad et al., 2020). Thus, the present study is the first survey performed in Iraq to explore the perspective of university academics on remote teaching during COVID-19 pandemic. Therefore, as stated above, this study tries to assess the university academic staff perspective on various aspects of remote teaching during COVID-19 pandemic and the findings might be helpful for teachers and policy makers to deal with the challenges of remote learning in the post-COVID-19 world.

\section{METHODS}

\section{Participants and procedure}

The identified participants in this study were university academics who were selected using convenience sampling. The sample consisted of 132 lecturers from different universities in Kurdistan region-Iraq. The data obtained from the selected sample was used to examine how the respondents report their perspectives on online learning.

\section{Measures}

In This study used a descriptive cross-sectional survey method. The data collection instrument was developed by the researcher in order to examine the academic staff perspective on online learning. The questionnaire used a five-point response scale ranging from 1 (strongly disagree) to 5 (strongly agree) and it was validated by specialists and experts.

The questionnaire was consisting of two sections. The first section included demographic data and the second section was related to the questions regarding the university academic staffs perspective on various aspects of online learning during COVID-19 pandemic. The questionnaire was distributed through the Google form on September 10, 2020 and was open until October 20, 2020. The links were shared with the university academics via the lecturers' university emails and Facebook group of lecturers. The data was received from the Google form and imported into the Statistical Package for Social Sciences (SPSS), version 21. 


\section{RESULTS AND DISCUSSION}

\section{Demographic Information}

Table 1 highlights the details of participants demographic information. Among 133 academic staff from different universities who participated in this study, only $25(18.8 \%)$ of them were females and 108 (81.2\%) lecturers were male. The age range of the participants were 25-58 and above: 55 participants (41.4\%) were from 36-46 age group, $24(31.6 \%)$ were from 25-35 age group, while $29(21.8 \%)$ of them were from 47-57 age group, and only 7 (5.3\%) were from 58 and above age group. Regarding participants' level of education, the majority of academics numbering 70 (52.6\%) was with master's degree, and 62 (46.6\%) were academics with PhD's degree. According to the demographic information, only 25 (18.8\%) of academics had prior experience in online teaching before Covid-19 pandemic, and the majority 108 (81.2\%) of them had no prior experiences regarding online learning.

\section{The academic staff perspective on various aspects of remote teaching}

Regarding the barriers that academics faced during online teaching process, as it is showed in Table 2, the majority of academics $(77.3 \%)$ responded that they had limited Internet access during online teaching process, and only $13.6 \%$ of them didn't face this problem. Additionally, electricity blackout problem during online teaching was another obstacle faced by the majority of academics (72.7\%), and only $21.2 \%$ of them didn't encounter it. Most of the academics (65.9\%) responded that they struggled in teaching practical subjects during online teaching process and only $18.2 \%$ of them disagreed with this statement. Regarding the responses of the academics for the statement "During the online teaching process, it was hard to be able to directly monitor my students", the majority of them (79.5\%) agreed, and only $9.8 \%$ disagreed to find it difficult.

Regarding the academic perspective towards the adequacy of implementing remote teaching, Table 3 showed that $56 \%$ of the academics agreed that online teaching is more adequate for theoretical rather than practical classes, and only $24.2 \%$ of them disagreed with this statement. In addition, $36.4 \%$ of the academics agreed with the statement "the recorded video lecture in class is more preferable than teaching online", and $38.6 \%$ of them disagreed. $73.8 \%$ of the academics agreed that it is better to implement online teaching and learning only for discussions between students and teachers, but $16.7 \%$ of them disagreed with this statement.

Regarding the academic perspective towards students' participation in remote teaching process, Table 4 showed that the majority of the academics (61.3\%) were not satisfied with the number of students who participated in their online lectures. Most of the respondents $(62.1 \%)$ mentioned that during the online class, some of the students virtually attended but did not pay attention to the lecture. Regarding low or high number of students' participations in online classes, $53.8 \%$ of the academics agreed to be associated to their ability of using technology. $31.8 \%$ of academics agreed that it is associated to the online class time, and most of them $36.4 \%$ disagreed with this statement. $72.8 \%$ of the academics believed that teachers were the only active participants in the online learning process.

Regarding the academics perspective towards their performance, Table 5 showed that $32.6 \%$ of them were satisfied in delivering the content of the subjects they have taught online to students, while $39.4 \%$ of them disagreed to be satisfied. Moreover, the majority of academics (79.5\%) agreed they were confident in preparation to teach online and only $7.6 \%$ of them disagreed with this statement. Only $25 \%$ of academics agreed that conducting online teaching was as easy as face-to face teaching, but most of them (49.2\%) disagreed with this statement.

Regarding the better administration of online teaching in academics perspective, Table 6 clearly showed that $78.1 \%$ of the respondents believed that university should provide effective and continuous trainings for teachers on online teaching. $71.9 \%$ of academics agreed that for better administration of online teaching process, constant followup from the faculties is needed. $69.7 \%$ of them believed that it is essential to take students feedback by lecturers and faculties. Additionally, $86.3 \%$ of academics agreed that for better administration of online teaching process, university should provide Internet access for students and lecturers. $87.1 \%$ of the respondents believed that it is necessary to prepare a specific structured module or plan to activate students in virtual learning environment. $87.2 \%$ of academics agreed that in order to ensure successful online learning, the university should provide the necessary tools for students and teachers.

As for academics perspective on student online assessment, Table 7 showed that the majority (64.4\%) of the respondents disagreed with the statement "the online assessment of students assignments was reliable". $49.2 \%$ of academics believed that online exams should have been conducted instead for the student assessments. However, most of the academics (88.6\%) believed that instead of online assessment, the exams should be conducted on campus but with measures in place to avoid the transfer of Covid-19.

When it comes to the lecturers' negative perspective towards online teaching, Table 8 illustrates that the majority of academics (58.3\%) believed that support and facilities provided by the university to the lecturers and students were not sufficient. Moreover, most of the academics (47\%) disagreed with the statement "the university identified adequate platforms for online teaching 
process". More than half of the respondents (59.9\%) mentioned that online teaching process should be deactivated. $66.6 \%$ of the academics lack the motivation to continue participating in online teaching process. Additionally, the vast majority of the respondents mentioned that online teaching process had no scientific base; instead, it was just a way to cross the study year.

Remote teaching and learning is a formidable task for academics and requires skills, abilities, facilities, and support for its successful implementation (Bhardwaj et al., 2015). The aim of this current study was to determine the university academic staff perspective on various aspects of remote teaching during the COVID-19 pandemic, such as the barriers of the process, the adequacy of implementation, students participation, academics performance, administration of remote teaching, student online assessment, and the lecturers' negative perspective towards remote teaching.

The findings of this current study showed that the majority of academics had limited Internet access during remote teaching process. Although limited access to the Internet and technology was a common problem faced by academics and students in many countries according to the recent studies (Judd et al., 2020; Zhong, 2020; Pace et al.,
2020; Lee, 2020; Barton, 2020; Kwabena \& Boateng, 2020), they mostly were from rural areas and from disadvantaged families (Mustafa, 2020). At the same time, in Kurdistan region-Iraq, the academics from any location were facing difficulties accessing the Internet with no exceptions. However, the majority of academics in this current study believed that to ensure successful online teaching and learning, the university should provide the necessary tools and free Internet access to students and teachers, which was also suggested by other studies (Barton, 2020; Kwabena \& Boateng, 2020).

The blackout problem during online teaching was another barrier faced by the majority of academics based on the findings of this current study, which was consistent with (Fawaz \& Samaha, 2020). The electricity and telecommunication deficit in Lebanon have been reported to be a significant barrier to e-learning as well. For instance, Gupta et al. (2020) found that $63.2 \%$ of students get disturbed during online class because of electricity problems. Thus, as it was stated by Fatma (2013), the lack of infrastructure in terms of connectivity, availability of the Internet and blackout problems are the major issues in developing countries.

Table 1. Participant's Demographic Information

\begin{tabular}{|c|c|c|c|}
\hline & & $\mathrm{n}$ & $\%$ \\
\hline \multirow[t]{2}{*}{ Gender } & Female & 25 & 18.8 \\
\hline & Male & 108 & 81.2 \\
\hline \multirow[t]{4}{*}{ Age } & $25-35$ & 24 & 31.6 \\
\hline & $36-46$ & 55 & 41.4 \\
\hline & $47-57$ & 29 & 21.8 \\
\hline & 58 above & 7 & 5.3 \\
\hline \multirow[t]{2}{*}{ Level of Education } & Master's degree & 70 & 52.6 \\
\hline & PhD's degree & 62 & 46.6 \\
\hline \multirow[t]{2}{*}{ Online learning prior experience } & Yes & 25 & 18.8 \\
\hline & No & 108 & 81.2 \\
\hline
\end{tabular}

Table 2. Obstacles faced by academics during online teaching process

\begin{tabular}{|c|c|c|c|c|}
\hline No. & Statement & Agree & Uncertain & Disagree \\
\hline 1 & The Internet access was poor during the online teaching process. & $77.3 \%$ & $9.1 \%$ & $13.6 \%$ \\
\hline 2 & I faced electricity blackout problem during online teaching process. & $72.7 \%$ & $6.1 \%$ & $21.2 \%$ \\
\hline 3 & In online teaching process, I struggled in teaching practical subjects & $65.9 \%$ & $15.9 \%$ & $18.2 \%$ \\
\hline 4 & During the online teaching process, it was hard to monitor my students directly & $79.5 \%$ & $10.6 \%$ & $9.8 \%$ \\
\hline
\end{tabular}

Table 3.Implementing remote teaching

\begin{tabular}{|c|c|c|c|c|}
\hline No. & Items & Agree & Uncertain & Disagree \\
\hline 1 & Online teaching is more adequate for theoretical classes rather than practical classes. & $56 \%$ & $19.7 \%$ & $24.2 \%$ \\
\hline 2 & The recorded video lecture in class is more preferable than teaching online. & $36.4 \%$ & $25 \%$ & $38.6 \%$ \\
\hline 3 & $\begin{array}{l}\text { It is better to implement the online teaching and learning only for discussions between } \\
\text { students and teachers. }\end{array}$ & $73.8 \%$ & $9.8 \%$ & $16.7 \%$ \\
\hline
\end{tabular}

Table 4. Academics' perspective towards students' participations in online learning

\begin{tabular}{|c|c|c|c|c|}
\hline No. & Items & Agree & Uncertain & Disagree \\
\hline 1 & I was satisfied with the number of students who participated in my online lectures. & $24.2 \%$ & $14.4 \%$ & $61.3 \%$ \\
\hline 2 & $\begin{array}{l}\text { during the online class, some of the students virtually attended but did not pay attention } \\
\text { to the lecture }\end{array}$ & $62.1 \%$ & $27.3 \%$ & $10.6 \%$ \\
\hline 3 & $\begin{array}{l}\text { The low or high number of students' participations in online class associated to their } \\
\text { ability of using technology }\end{array}$ & $53.8 \%$ & $29.5 \%$ & $16.7 \%$ \\
\hline 4 & the low or high number of students participation were associated with online class time & $31.8 \%$ & $31.8 \%$ & $36.4 \%$ \\
\hline 5 & Teachers were the only active participants in the online learning process. & $72.8 \%$ & $14.4 \%$ & $12.8 \%$ \\
\hline
\end{tabular}


Table 5. Academics' perspective towards their performance

\begin{tabular}{|c|c|c|c|c|}
\hline No & Items & Agree & Uncertain & Disagree \\
\hline 1 & I was satisfied in delivering the content of the subjects I taught online to students. & $32.6 \%$ & $28 \%$ & $39.4 \%$ \\
\hline 2 & I was confident in preparation to teach online. & $79.5 \%$ & $12.9 \%$ & $7.6 \%$ \\
\hline 3 & Conducting online teaching was as easy as face-to face teaching & $25 \%$ & $25.8 \%$ & $49.2 \%$ \\
\hline
\end{tabular}

Table 6. Academics' perspective for better administration of online teaching

\begin{tabular}{|c|c|c|c|c|}
\hline No & Items & Agree & Uncertain & Disagree \\
\hline 1 & $\begin{array}{l}\text { University should provide effective and continuous trainings for teachers on online } \\
\text { teaching. }\end{array}$ & $78.1 \%$ & $7.6 \%$ & $14.3 \%$ \\
\hline 2 & $\begin{array}{l}\text { for better administration of online teaching process, constant follow-up from the faculties } \\
\text { is needed }\end{array}$ & $71.9 \%$ & $14.4 \%$ & $13.6 \%$ \\
\hline 3 & $\begin{array}{l}\text { for better administration of online teaching process, it is essential to take students } \\
\text { feedback by lecturers and faculties }\end{array}$ & $69.7 \%$ & $9.1 \%$ & $21.2 \%$ \\
\hline 4 & $\begin{array}{l}\text { for better administration of online teaching process, university should provide internet } \\
\text { access for students and lecturers }\end{array}$ & $86.3 \%$ & $6.8 \%$ & $6.8 \%$ \\
\hline 5 & $\begin{array}{l}\text { It is necessary to prepare a specific structured module or plan to activate students in } \\
\text { virtual learning environment. }\end{array}$ & $87.1 \%$ & $3.8 \%$ & $9.1 \%$ \\
\hline 6 & $\begin{array}{l}\text { For ensuring a successful online learning; the university should provide the necessary } \\
\text { tools for students and teachers. }\end{array}$ & $87.2 \%$ & $3.8 \%$ & $9 \%$ \\
\hline
\end{tabular}

Table 7. Academics' perspective towards online assessment

\begin{tabular}{|c|c|c|c|c|}
\hline No & Items & Agree & Uncertain & Disagree \\
\hline 1 & The online assessment of students' assignments was reliable. & $19.7 \%$ & $15.9 \%$ & $64.4 \%$ \\
\hline 2 & For the students' assessment; the online exams should have been conducted. & $49.2 \%$ & $18.9 \%$ & $31.8 \%$ \\
\hline 3 & $\begin{array}{l}\text { Instead of the online assessment, the exams should be conducted in university halls with } \\
\text { taking intensive measures. }\end{array}$ & $88.6 \%$ & $5.3 \%$ & $6 \%$ \\
\hline
\end{tabular}

Table 8. Academics' negative perspective towards online teaching

\begin{tabular}{|c|c|c|c|c|}
\hline No & Items & Agree & Uncertain & Disagree \\
\hline 1 & The university provided sufficient supports and facilities to lecturers and students. & $24.3 \%$ & $17.4 \%$ & $58.3 \%$ \\
\hline 2 & The university identified adequate platforms for online teaching process. & $31.8 \%$ & $21.2 \%$ & $47 \%$ \\
\hline 3 & The online teaching process should be deactivated. & $59.9 \%$ & $22 \%$ & $18.2 \%$ \\
\hline 4 & Teachers lack the motivation to continue participating in the online teaching process. & $66.6 \%$ & $21.2 \%$ & $12.1 \%$ \\
\hline 5 & $\begin{array}{l}\text { This online teaching process had no scientific-base; it was just a way to cross the study } \\
\text { year. }\end{array}$ & $73.4 \%$ & $12.1 \%$ & $14.4 \%$ \\
\hline
\end{tabular}

In addition, most of the academics struggled in teaching practical subjects during remote teaching process and they believed that this process is more adequate for theoretical rather than practical-based classes. This finding was consistent with (Sen et al., 2020) who stated that students and teachers who belong to the domain of practical-based subjects faced serious problems in taking practical classes. Likewise, (Kumar, 2020) believed that laboratory-based classes cannot be held online. Therefore, in this current study some of the academics preferred recorded video lecture in class rather than teaching online. The majority of scholars believed that it is better to implement remote teaching and learning only for discussions between students and teachers as remote teaching is mainly applicable to the theory classes only (Gupta et al., 2020), whereas the practical-based subjects need hand-to-hand trainings which is almost impossible to be done online.

Based on the academics perspective in this current study, teachers were the only active participants in the online learning process, which was also reported by (Barton, 2020) who claimed that online learning appeared to be less student-centered. They explained that this could be due to less interaction between teachers and students in remote learning in comparison with the traditional class. Additionally, the class size might be another factor that affects student participation (Parks-Stamm et al., 2017). The majority of the academics believed that it is necessary to design a specific structured module or plan to activate students in virtual learning environment as well as a constant follow-up from the faculties is needed for better administration of remote teaching.

Accordingly, it was hard for the academics to directly monitor their students, and they believed that students were not paying attention to the lecture based on the findings of this current study. This was consistent with Sharifov, and Mustafa (2020) who stated that the majority of learners may not achieve their learning goals as their progression is not monitored physically, and as a result, the learners become lazy. In areas where online learning is applied, districts are encouraged to monitor student participation and performance (Tadayon, 2020). Therefore, monitoring student participation and patterns of participation closely can help instructors identify student needs accordingly (Vonderwell \& Zachariah, 2008). However, most of the academics in this current study believed that for better administration of remote teaching, 
it is essential to take students feedback by lecturers and faculties.

Moreover, in this study academics were unsatisfied with the students' attendance, and this could be due to the limited access to the Internet. Most of the academics believed that low participation rate was associated with their competency of using technology; while some of them believed it was associated with online classes timing (Sen et al., 2020).

Although the majority of the academics were confident in preparation to teach online, most of them were unsatisfied in delivering the classes they taught online. This could be due to the lack of availability of study materials for both students and teachers. The other reason might be the fact that the academics are accustomed to follow traditional set up of face-to-face classes, thus remote teaching was entirely a new concept for them (Sen et al., 2020; Dhawan, 2020; Imran, \& Siddiqui, 2020; Sarwar, et al., 2020). The speed with which this move to online instruction was expected to happen is unprecedented and staggering (Hodges \& Fowler, 2020). For this reason, the majority of academics in this study believed that remote teaching had no scientific base and it was just a way to survive the study year.

Nevertheless, this study has showed that the majority of academics discovered that remote teaching was not as easy as face-to face teaching. This could be due to the lack of academics competency in implementing remote teaching. Thus, knowing the ability and willingness of lecturers to use technology is a key competence, necessary for learning and teaching (Abdul-Rahman, \& Abdullah, 2017). Poor computer skills of faculty staff and students are considered to be a challenge in implementing remote learning (Gaur et al., 2020). In Arab universities, to a large extent professors lack the prior training in the usage of technology (Lassoued, Alhendawi, Bashitialshaaer, 2020). Accordingly, the majority of the academics believed that university should provide effective and continuous trainings on online teaching, which was also suggested by (Bhardwaj et al., 2015). Training to support e-learning and teaching is needed to enable smooth transition of the faculty staff from their traditional teaching methods into a blended approach.

Furthermore, this research revealed that the majority of the academics believed that support and the facilities provided by university to lecturers and students were insufficient. For instance, the lack of compatible online platforms for remote teaching (Gaur et al., 2020), or the financial barriers, as stated by (Zeng et al., 2017) can also impede students to keep up with their online learning. Thus, most of academics lack motivation to continue participating in remote teaching process, and they believed that remote teaching should be deactivated. This was consistent with (Lassoued, Alhendawi, Bashitialshaaer,
2020) findings that some teachers in Arab universities may have negative attitudes towards online teaching.

According to the academics, online assessment of students was not reliable, which was also reported by the other study stating that it is easier to validate assessments in traditional physical classrooms as compared to onlinebased classrooms that involve some level of digital literacy and this may affect the reliability of the assessments in online-based classrooms (Sharifov \& Mustafa, 2020).

More distinctly, Iraqi universities conducted the final exams online via the Edmodo platform (Sherwani, 2020). However, due to the different study systems in Kurdistan region universities (e.g. semester-based, annual-based), the assessment methodology of final exams were also different. Consequently, examinations for students who were studying on an annual basis were canceled (Shilani, 2020), while students who were studying on a semester basis were required to prepare and present an academic assignment online.

Additionally, some of the academics believed that conducting online exams as an assessment methodology was more appropriate than just presenting an assignment online. However, the majority of the academics believed that instead of online assessment, the exams should be conducted in university examination halls with taking intensive measures, because applying assessments online on those courses designed for face-to-face learning is a challenging task (Sahu, 2020). In short, although online education was the best option for preventing the spread of the COVID-19, online teaching has so far proven to be less effective than traditional on campus teaching (Sen et al., 2020). Especially, with the barriers mentioned above in mind, precisely, as it was stated by (Adnan, \& Anwar, 2020), online learning cannot produce desired results in underdeveloped and developing countries.

\section{CONCLUSION}

By undertaking this study, the findings highlighted the current situation of online learning at universities in Kurdistan region-Iraq based on academics' personal experiences. The present study contributed to the existing literature, as there is an obvious lack of research has been conducted yet on university academics' perspective regarding the remote teaching during Covid-19 pandemic in Iraq. This current research provided important insights for the policy makers in higher education to scrutinize the aspects that hinder the process of remote teaching in Iraq.

Some suggestions can be drawn according to the findings such as, establishing compatible online teaching platforms by the university to facilitate the process for both lecturers and students are essential. A reliable mode of assessment should be designed specifically for online learning to assess students' performance. Additionally, providing effective and continuous trainings on online 
teaching for academics to increase their competency of implementing online teaching is needed. Providing an effective free Internet access to both lecturers and students is essential for implementing online learning process.

\section{Acknowledgement}

The authors would like to thank all parties who have assisted in the research and writing of this manuscript so that it deserves to be widely published to the academic community.

\section{REFERENCES}

Ahsanah, F. (2015). "Group Investigation": A Cooperative Learning Method for the 10 Th Grade Students in Speaking the GI Method. TELL Journal, 3(1), 57-69.

Adnan, M., \& Anwar, K. (2020). Online learning amid the COVID-19 pandemic: Students' perspectives. Journal of Pedagogical Sociology and Psychology, 2(1), 45-51.

https://doi.org/10.33902/JPSP.2020261309

Tadayon, A. (May 11, 2020). Teachers grapple with how to keep track of students during distance learning, https://edsource.org/2020/teachers-grapple-with-how-to-keeptrack-of-students-during-distance-learning/631189

Arnou, Ch., Cornelis, G., Jan, P. H., Howard, S. K., Leemans, G. (2020). COVID-19 and educational spaces: Creating a powerful and social inclusive learning environment at home. Retrieved, August 20, 2020,

https://www.researchgate.net/publication/341205829

Bao, W. (2020). COVID-19 and online teaching in higher education: A case study of Peking University. Hum Behav \& Emerg Tech. 2:113-115. https://doi.org/10.1002/hbe2.191

Barboni, L. (December 12, 2019). From shifting earth to shifting paradigms: How webex helped our university overcome an earthquake. CISCO, Upshot by Influitive.

https://upshotstories.com/stories/from-shifting-earth-toshifting-paradigms-how-webex-helped-our-university-overcomean-earthquake

Bhardwaj, A., Nagandla, K., Swe, K.M.M., Abas, A.B.L. (2015). Academic Staff Perspectives Towards Adoption of ELearning At Melaka Manipal Medical College: Has ELearning Redefined Our Teaching Model?. Kathmandu Univ Med J,49(1):12-8.

Barton, DC. (2020). Impacts of the COVID-19 pandemic on field instruction and remote teaching alternatives: Results from a survey of instructors. Ecol Evol, 00:1-9. https://doi.org/10.1002/ece3.6628

COVID-19 Educational Disruption and Response, UNESCO. 202003-04. Retrieved 2020-08-12

https://en.unesco.org/news/covid-19-educationaldisruption-and-response

Crawford, J., Butler-Henderson, K., Rudolph, J., \& Glowatz, M. (2020). COVID-19: 20 countries' higher education intraperiod digital pedagogy responses. Journal of Applied Teaching and Learning (JALT), 3(1).

https://doi.org/10.37074/jalt.2020.3.1.7
Duraku, Z.Y. \&Hoxha, L. (2020). The impact of COVID-19 on education and on the well-being of teachers, parents, and students: Challenges related to remote (online) learning and opportunities for advancing the quality of education. www.researchgate.net/publication. Accessed 24/8/2020.

Farfán-Cano, G. (2020). A Perspective about Coronavirus Disease 2019 (COVID-19). Digital scientific journal INSPILIP. 4(2),

Guayaquil, Ecuador. (2019). A perspective about Coronavirus Disease 2019 COVID-19.

https://www.researchgate.net/publication/340076911_A_perspe ctive_about_Coronavirus_Disease_2019_COVID-19

Fatma S. F. (2013), E-Learning Trends Issues and Challenges, International Journal of Economics. Commerce and Research, 3 (2), pp. 1-10.

http://www.tjprc.org/publishpapers/2-41-1363675286-1.ELearning..Shaikh.full.pdf

Favale, T., Soro, F., Trevisan, M., Drago, I., \& Mellia, M. (2020). Campus traffic and e- Learning during COVID19 pandemic. Computer Networks, 176,

https://doi.org/10.1016/j.comnet.2020.107290

Fawaz M, Samaha A. (2020). E-learning: Depression, anxiety, and stress symptomatology among Lebanese university students during COVID-19 quarantine. Nursing Forum, 1-6. https://doi.org/10.1111/nuf.12521

Gaur, U., Majumder, M.A., Sa, B. et al. (2020). Challenges and Opportunities of Preclinical Medical Education: COVID-19 Crisis and Beyond. SN Compr. Clin. Med, 2, 1992-1997. https://doi.org/10.1007/s42399-020-00528-1

Gupta A, Shrestha RM, Shrestha S, Acharya A, \& Pandey N. (2020). Perception of BDS students of Kathmandu University on online learning during COVID-19 pandemic. Orthodontic Journal of Nepal, 10(2).

https://www.nepjol.info/index.php/OJN/article/view/31064

Hodges, Charles B. Fowler, Denver J., (2020), The COVID-19 Crisis and Faculty Members in Higher Education: From Emergency Remote Teaching to Better Teaching through Reflection, International Journal of Multidisciplinary Perspectives in Higher Education, 5(1). pp. 118-122 https://ojed.org/jimphe

Ibrahim, A., Al Kaabi, A., \& El Zaatari, W. (2013). Teacher resistance to educational change in the United Arab Emirates. International Journal of Research Studies in Education, 2(2):1-11, doi: 10.5861/ijrse.2013.254

Judd, J., B. A. Rember, T. Pellegrini, B. Ludlow, and J. Meisner. (2020). "This Is Not Teaching': The Effects of COVID-19 on Teachers.

https://www.socialpublishersfoundation.org/knowledge_base/th is-is-not-teaching-the-effects-of-covid-19-on teachers/

Raymond, Kau, Gurpreet. (2020). New Phase in Education due to COVID-19, International Journal of Creative Research Thoughts (IJCRT), Volume 8, Issue 5, www.ijcrt.org

Kumar, Pramod. Reference Based Study on Impact Of Covid-19 On Education Systems, Proceedings of Cloud based International Workshop 25th July, 2020 Organized by sbytetechnologies.com, www.researchgate.net/publication. Accessed 15/9/2020. 
Lassoued, Z.; Alhendawi, M.; Bashitialshaaer, R. An Exploratory Study of the Obstacles for Achieving Quality in Distance Learning during the COVID-19 Pandemic, Educ. Sci. 2020, 10, 232; doi:10.3390/educsci10090232. www.mdpi.com/journal/education

Lee K. (2020). Coronavirus: universities are shifting classes online-but it's not as easy as it sounds. The Conversation, 9 March. Available at:

https://theconversation.com/coronavirus-universitiesareshifting-classes-online-but-its-not-as-easy-as-itsounds-133030 (accessed 18 September 2020).

Mustafa, N. (2020). Impact of the 2019 - 20 coronavirus pandemic on education. International Journal of Health Preference Research, 1-36. doi:10.13140/RG.2.2.27946.98245

Pace, Christi; Pettit, Stacie K.; and Barker, Kim S. (2020) "Best Practices in Middle Level Quaran teaching: Strategies, Tips and Resources Amidst COVID-19," Becoming: Journal of the Georgia Association for Middle Level Education: 31 (1), Article 2. doi: 10.20429/becoming.2020.310102

Parks-Stamm, E. J., Zafonte, M., \& Palenque, S. M. (2017). The effects of instructor participation and class size on student participation in an online class discussion forum. British Journal of Educational Technology, 48(6), 1250- 1259. https://doi.org/10.1111/bjet.12512|

Upoalkpajor, JN., Upoalkpajor, CB. (2020). The Impact of COVID19 on Education in Ghana. Asian J of Edu and Social Std. 2020;9(1):23-33. https://doi.org/10.9734/ajess/2020/v9i130238

Ullah Irshad, Irshad Aamna . 2020. COVID-19 and Its Effect on Education System, International Journal of Research Scholars, Volume 4, Issue 1, ISSN: http://www.ijrs.pk

Sahu, Pradeep. 2020. “Closure of Universities Due to Coronavirus Disease 2019 (COVID-19): Impact on Education and Mental Health of Students and Academic Staff." In.: Cureus, 12(4). doi: 10.7759/cureus.7541

Sarwar, Huma, Hira Akhtar, Meshal Muhammad Naeem, Javeria Ali Khan, Khadija Waraich, Sumaiya Shabbir, Arshad Hasan, and Zohaib Khurshid. (2020). Self-Reported Effectiveness of e-Learning Classes during COVID-19 Pandemic: A Nation-Wide Survey of Pakistani Undergraduate Dentistry Students. European journal of dentistry, 14(S 01), S34S43. https://doi.org/10.1055/s-0040-1717000

Sen Suhel, Chatterje Shrayashi, Das Ankita. (2020). Problems of Online Education System in South Bengal During the Covid-19 Pandemic: An Appraisal. Journal of Humanities and Social Science (IOSR-JHSS), 25(10), 07-20.

www.iosrjournals.org

Shahzad, A., Rohail Hassan, Adejare Yusuff Aremu, Arsalan Hussain, and Rab Nawaz Lodhi. (2020). Effects of COVID19 in E-learning on higher education institution students: the group comparison between male and female. Quality \& Quantity, 1-22. https://doi.org/10.1007/s11135-020-01028-z

Shahzad, S. K., Hussain, J., Sadaf, N., Sarwat, S., Ghani, U., \& Saleem, R. (2020). Impact of Virtual Teaching on ESL Learners' Attitudes under COVID-19 Circumstances at Post Graduate Level in Pakistan. English Language Teaching, 13(9), 1-9. doi: 10.5539/elt.v13n9p1
Sherwani, H. (2020, May 26, 12:44). Iraq's universities, colleges to take final exams online amid COVID-19: Ministry of Higher Education, https://www.kurdistan24.net/en/news/91ad8fac7819-45d4-aaf1-2eb90e74ce13

Shilani, H. (2020, May 26, 19:59), Kurdistan announces year's end for higher education; no final exams,

https://www.kurdistan24.net/en/news/d1fab625-861d-4144990e-e82248321d39

Shivangi, D. (2020). Online Learning: A Panacea in the Time of COVID-19 Crisis. Journal of Educational Technology. 49, 522. DOI: $10.1177 / 0047239520934018$

Stern, A et al. (2009). Closing the schools: lessons from the 191819 U.S Influenza Pandemic. Health Affairs 28: w1066w1078. https://doi.org/10.1377/hlthaff.28.6.w1066

Vonderwell, S., Zachariah, S. (2008). Factors that influence participation in online learning. Journal of Research on Technology in Education, 32:213-230.

https://files.eric.ed.gov/fulltext/EJ728902.pdf

Sharifov, M., \& Mustafa, A. S. (2020). Review of Prevailing Trends, Barriers and Future Perspectives of Learning Management Systems (LMSs) in Higher Institutions. The Online Journal of New Horizons in Education, 10(3), 166.

https://www.researchgate.net/publication/343304876_Review_o f_Prevailing_Trends_Barriers_and_Future_Perspectives_of_Learnin g_Management_Systems_LMSs_in_Higher_Institutions

Subedi, S., Nayaju S., Shah, S., Shah, J. (2020). Impact of E-learning during COVID-19 Pandemic among Nursing Students and Teachers of Nepal. International Journal of Science \& Healthcare Research, 5(3), 68-76.

Yokozeki: UNESCO. (2020, March 30). COVID-19 Webinar: A new world for teachers, education's frontline workers. Marrë nga https://en.unesco.org/news/covid-19-webinar-newworldteachers-educations-frontline-workers View publication

Zeng Y, Wang G, Xie C, Hu X, Reinhardt J. Prevalence and correlates of depression, anxiety and symptoms of stress in vocational college nursing students from Sichuan, China: a cross-sectional study. Psychol Health Med. 2019;24(7):798-811. https://doi.org/10.1080/13548506.2019.1574358

Zhong, R. (2020, March 17). The coronavirus exposes education's digital divide. The New York Times. https://www.nytimes.com/2020/03/17/technology/chinaschoolscoronavirus.html. 